\title{
Women, the Employment Contracts Act and bargaining: a discussion paper
}

\author{
Janet Sayers*
}

This paper discusses some of the issues that arise from the Employment Contracts Act for women and bargaining. These issues are discussed in the contexts of likely future trends in female labour force participation. The paper addresses the topics under the following general headings: the structural location of women in an increasingly fragmented labour market and the impact of that on women's bargaining power; socialization and perceptions of women's bargaining effectiveness; and the impact of the social policy initiatives of the New Right on women's employment choices.

\section{Introduction}

The Employment Contracts Act is an instrument of the New Right. The aim of this initiative in labour market policy is to create a pure, market driven, labour force with minimal intervention from the centre in its workings. The idea that the individual is a free agent is primary to New Right philosophy: the individual has the power to choose among alternatives in a free exchange among employers and employees. This philosophy emphasizes "the supremacy of the individual [and the] virtue of stability of the free market with opposition to almost any form of state intervention" (Armstrong, 1989, p.11).

The repeal of the Employment Equity Act 1990 by the present National Government was also in keeping with this philosophy. New Right philosophy prescribes that equity will arise out of the marketplace and that interventionist legislation is unnecessary (Lewis, 1991, p.124).

This ideology, which is encapsulated in the Employment Contracts Act, is particularly problematic for women (along with other groups of vulnerable workers) in a number of ways. The following discussion provides an introduction to some of the issues and broad themes that could well form the subject of research.

\section{Women and bargaining}

The Employment Contracts Act will affect women on a number of different levels. Women are located in the following 3 groups in the labour market: first, a group of elite women workers who are well educated with flexible work skills and either no family commitments or enough resources to minimize the impact of family responsibilities on their working lives; second, the vast majority of full-time women workers who mainly occupy the clerical and service sectors; third, women in the informal economy (Pahl, 1989) which includes women on benefits, homeworkers, part time workers, the unemployed and voluntary workers (Power, 1988). 
As well as the recognition of the differential effects of the Employment Contracts Act on these groups, the Act must also be seen in conjunction with a number of other state initiatives such as the repeal of the Employment Equity Act 1990 and the recent benefit cuts:

The benefit cuts widen the gap between benefits and wages ... those on benefits will have the "incentive" to end their ... dependency on the state and find a job; wages will fall as the beneficiaries underbid the low paid for jobs ... (Campbell, 1991, p.17).

A philosophy of non-intervention in the labour market was the prime motivation for the repeal of the Employment Equity Act 1991. The aim of non-intervention policies is to create a pure market-driven labour force. One of the intended outcomes of this policy is to heighten competition for low paid work so that fixed employment costs can be driven down (Boyer, 1987). Women, along with young workers, part time workers and agricultural workers, are identified by the Low Pay Unit of the Department of Labour as being a main group of concern for low pay research.

The following discussion examines issues of concern for women under 3 general headings: structural locations of women in the workforce, bargaining issues and social policy impact on the opportunities of women.

\section{Structural factors}

The economic policies of the New Right need to be seen in the contexts of fundamental social changes that are occurring in the western world. The following quote encapsulates several of the concepts signified by New Times and highlights the importance of changing labour processes in the western world's movement towards New Times.

... coming to grips with New Times means first understanding what New Times are, what they mean. At the heart of New Times is the shift from the old mass production Fordist economy to a more flexible post-Fordist order based on computers, information technology and robotics. But New Times are about more than economic change. Our world is being remade. Mass production, the mass consumer, the big city, the big brother state, the sprawling housing estate, the nation state are in decline: flexibility, diversity, differentiation, mobility, communication, decentralisation and internationalisation are in the ascendent. In the process our sense of self, our own subjectivities, are being transformed. We are in transition to a new era (Maharey and Cheyne, 1990, p.2).

Neilson (1990) suggests that New Times and post-Fordism are coming to New Zealand. The structural characteristics of the new workforce will reflect both the past Fordist work processes and those of the new post-Fordist order. ${ }^{1}$ These are diagramatically represented in figure 1 .

Women are likely to predominate in the sectors of vulnerable workers illustrated (Mumford, 1989; Neilson, 1990). Women presently concentrated in the lower service sector are likely to be particularly vulnerable because the impact of the introduction of technology may mean a decreasing amount of work available in this sector, or at the very least a deskilling of the work in which women predominate (Couchman, 1984; Brocklesby, 1984).

1 See Sites, Autumn 1990, for a series of articles on the application of New Times and postFordism to New Zealand. 
Figure 1: Core and vulnerable work processes of the future

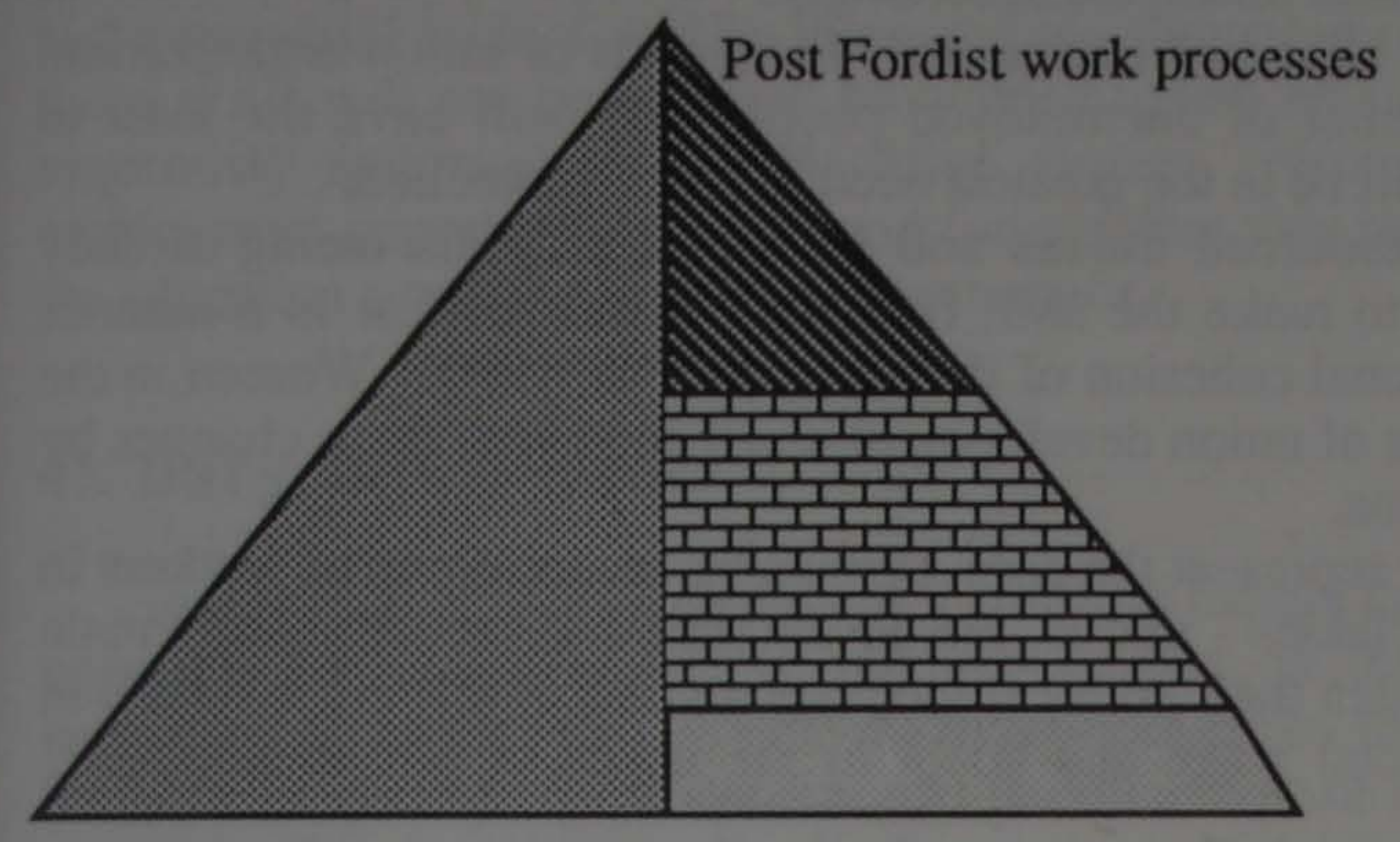

Old Fordist work processes

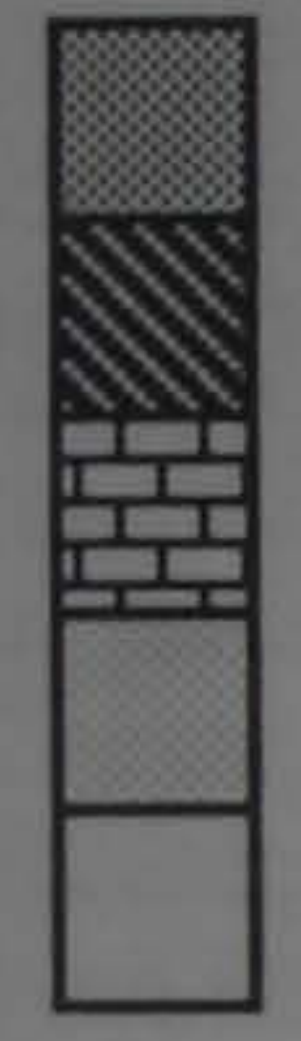

Multi-production sector

Elite service sector

Routine service sector

Servicing class

Fordist work processes

Stable, secure core employment

Vulnerable employment

The second group of vulnerable workers will exist both in the old Fordist work process framework and as a casualized temporary workforce in the "twilight" of the economy. This group will dramatically increase to perform the remaining unskilled work which will include unskilled "low-tech" and low pay work. These industries will demand low cost, part time, contract labour. Endwick (1989, p.128) commented with reference to multinational employment that female manual workers, particularly in developing countries, are mainly employed in unskilled or semi-skilled jobs in labour intensive industries where traditionally perceived female traits, manual dexterity and willingness to perform repetitive tasks, are valued and there is a low level of union organization.

The third group of vulnerable workers will be the class of workers that will emerge to service the elite service class. Post-Fordism predicts that the elitist service class will demand a service of its own such as maids, gardeners, child care workers, domestic workers, waiters, bar staff, hotel and restaurant workers. Neilson (1990) comments:

These developments signal the emergence of a flexible, casualised workforce for which capital has minimalised its obligations and maximised its returns, as well as a new underclass of tertiary sector workers employed either directly or indirectly out of the earnings of the service class (p.87).

One of the fundamental problems associated with these structural changes will be in the area of trade union organization. Women are mainly marginalized into service, part time and domestic work and have a comparatively low level of trade union consciousness and membership. For example, workers in the early childhood sector, which has recently achieved a level of union organization, still suffer from very strong traditional views about the nature of their work. This has both created extremely low rates of pay and contributed to a low union participation rate (Cook, 1984). The Combined Early Childhood Union of Aotearoa recently expressed their fear that the Employment Contracts 
Act would severely weaken the progress they have made in organizing collectively to redress undervaluation of their labour. For many years their labour has been perceived as being "women's work" and has been underpaid accordingly.

These "domestic" workers have had traditionally low levels of union organization. Along with an increasing number of unemployed people they will have the least to bargain with industrially and will be in the greatest need of union protection.

The dilemma for under-resourced unions and for union officials facing already impossible workloads is how to make the shift from Old Times to New in a manner which maintains the organizational cohesion of the union (Walsh, 1990). Women in the trade union movement, in terms of union development, must cope with these changes by analysing the following questions.

First, will unions primarily represent the core, permanent secure group of workers in the service and technological classes - that is, the advantaged and predominantly male sector? Second, will they broaden their political ideology and become more involved in the areas of social policy, social wage and adapt to the needs of the unemployed? (Neilson, 1990).

This likely trend for women to be marginalized to the periphery of the labour is further exacerbated by the lack of movement of women into the managerial and professional occupations which will provide the core stable work in the future. Evidence suggests that women will not move into the core stable elite class of service workers in any great numbers. Numbers have been static in this area for some time. Lewis (1991) comments:

The perception is that work opportunities are increasing for women and women are filling high status positions. British research suggests that this is false. A few women have been promoted to highly visible leading positions. This leads to the belief that all women can make it to the top. In practice, the location of women is either unchanging, or more alarmingly, deteriorating (p.125).

A brief analysis of 2 key documents, the "Porter Report" and Tomorrow's skills, provides interesting insights into key areas of future secure employment and the danger of the present government's policies exacerbating women's employment disadvantages.

The "Porter Report" identifies a number of factors that interfere with New Zealand's competitive advantage. This report endorses the Employment Contracts Act as a "step in the right direction" (Crocombe et al., 1991, p.173) but also observes that labour market policy should ensure that the opportunities and incentives are in place to facilitate skills upgrading. The report recommends upgrading technical, scientific, managerial, mathematical, and engineering skills, as well as language skills, most particularly Japanese, mathematics, science and engineering. Multi-skilling is identified as being a key component in business development and competitiveness. Strained labour relations are blamed in the report for limited investments in new technology which is seen as being essential to sustained economic growth. Investment in research and development is the key to competitive advantage, producing superior, differentiated products.

Tomorrow's skills (New Zealand Planning Council, 1990), another document concerned with the future identifies the move to information intensive jobs, the move to service sector employment and the move away from manual work as clear trends in New Zealand employment over the last 15 years. Less easy to predict is the skill requirements of the "new economy". However, several significant trends are identified, and conclusions are drawn as to the type of workforce required for the future in New Zealand. The faster growing occupations will require higher levels of education. There will be growth in the numbers of self-employed and part time employed. In the near future the fastest growing areas of employment will be the business and finance sector, the restaurant and hotel sector and the community/personal service sectors. 
The "Porter Report" and Tomorrow's skills clearly identifies what is needed in terms of work processes and skill development in the future workforce. They are multi-skilled production systems, rapid technology implementation, high skill levels in the technical and managerial sectors, and an increased investment in research and development. But these skills will not be acquired by women unless equal educational opportunities are vigorously endorsed in the education system. Women will never achieve equal employment opportunities in the workforce unless they receive the same opportunities in the education system as their male counterparts.

\section{Bargaining issues}

In this second area of discussion I consider factors that will limit women's ability to negotiate individual contracts and that impact on the strength of their collective bargaining arrangements. Women are disadvantaged by the Employment Contracts Act as individuals, collectives of women, and in collectives of men and women. I believe the reason for this disadvantage lies in the emphasis of the Employment Contracts Act on an individualistic, anti-collectivistic philosophy that implicitly condones self-interested behaviour, thereby discriminating against more altruistic motivations.

Women are fundamentally disadvantaged when bargaining individual contracts because of the way that they are socialized and perceived as women, the impact of care commitments on choice, and the effect of present structural inequalities. Women are socialized into thinking that the work they do is worth less than the work men do. Consequently women will generally expect to be paid less for doing similar work. Furthermore, both women and men consistently undervalue the performance of women even when the work being evaluated is performed identically by both genders (Deaux, 1988; Matlin, 1987).

Women tend to put the interests of others before their own. This tendency limits the choices that women are able to make in the labour market in a system where individual self-interest is elevated to the level that it is in the Employment Contracts Act. This can only severely limit women's choices further. This point is discussed below in relation to recent social policy initiatives.

Most women have less to negotiate with as they are already disadvantaged in the labour market. The average earnings of women are less than average male earnings, and women, on average, are less skilled and educated than their male counterparts (Department of Statistics, 1990). Women have not had the opportunities in the past, and cannot gain overnight the skills and the education that they need to compete in this sort of fashion. In reality, there will be little choice or freedom for women.

Women negotiating collectively are also at a disadvantage in relation to their male counterparts. Women negotiating as a group will suffer the same problems relating to stereotyping that they would as individuals. For example, workers in the early childhood sector still suffer from very strong traditional views about the nature of their work which has not only created extremely low rates of pay but has also contributed to a low union participation rate (Cook, 1984, p.7).

Additionally women are vulnerable collectively because they do not have the economic clout that traditional "male" occupational groups have; they are less organized and easier to undercut because of competition with the unemployed. The limiting impact of these factors on collective bargaining by women can be seen in examining recent cases of bargaining effectiveness of predominantly female groups. This points to the importance of economic clout in effective industrial action and trade union solidarity.

The difficulties that women workers may have with industrial action is illustrated by examining a group of predominantly female workers in the New Zealand Wool Testing Authority. This group of workers, 90 percent female, took action over the period November 1986 to April 1987 in an initial conflict over wage increases, safety issues and 
the general lack of an award (Gray, 1987). The workers had a relatively strong economic bargaining position but their power was severely eroded by the fact that colleagues did not support the strike. An additional factor which contributed to the eventual failure of the industrial action for the union was a high unemployment rate, and therefore a labour pool willing and able to undercut the wool workers.

Another example demonstrates how the views about the nature of "women's work" can impact on strike effectiveness even when the group is well organized. Nurses recently proposed a 24 hour strike on 29 and 30 April in the health sector but this was stopped by court injunctions. The main reason given for the successful court injunctions was concern for "patient safety". Nurse's feelings ran high over their right to use industrial muscle to protect their profession but the "caring" nature of the work counted against their ability to strike effectively (McMorran, 1991).

A further potential problem that may arise for female bargaining voices relates to the movement towards site bargaining signalled by the Employment Contracts Act. It is clear that at least 2 predominantly female unions, who have been significant in promoting issues about women workers in areas such as pay equity, will probably be weakened significantly by the movement to site bargaining. These are the Clerical Workers' Union and the Distribution Workers' Union; unions that represent predominantly women workers who work in diverse workplaces. As site bargaining evolves, these workers will be absorbed into larger site unions. Effectively this will dilute the women's voice under the typical hierarchical structure which is likely to prevail.

\section{Social policy}

This third area of discussion relates to both the post-Fordist vision of labour structures and the area of social policy. One of the effects of the decrease in the welfare state, complemented by increasing competition for low paid work, will be an expansion in the area of women's "unpaid" work. Power (1988) commented on the implementation of this policy in the US;

... the Reagan administration argued that its cuts in social spending should be compensated for by an increase in "volunteerism", the voluntary assumption of responsibility for these services by private organisations and individuals. In addition, the family should take on more responsibility for the care of the sick, handicapped, and elderly family members (p.154).

This assumption of "voluntarism" by the New Right will affect choices that New Zealand women make about employment. This trend, coupled with the impact of an increase in the "informal economy", such as home-working arrangements, will mean that we need to rethink the ways that work and unemployment are defined in New Zealand society.

The issue of unemployment is by no means resolved by Government labour market policy. It seems clear from consideration of post-Fordism that work will become increasingly casualized, part time, and that even those with high skill levels may experience periods of unemployment. With the "hidden" unemployed being a larger group, problems in identifying women's unemployment will become accentuated (Shipley, 1982).

\section{Conclusion}

I started this paper by defining 3 groups of women workers in the economy. For each of these groups the Employment Contracts Act has quite distinct implications. 
The 3 groups of women in the particularly vulnerable area of employment, the casualized periphery of the workforce, service support for the elite class and involved in old Fordist work processes, are likely to face increased competition for low paid work. In essence, these women will have little bargaining strength because they often have high care commitments which are likely to increase, union organization will be weak and the Employment Contracts Act weakens redress for workers in cases of employer abuse. The periphery workforce is where there are most likely to be problems and where there will be the least resources to deal with these problems.

In the service sector there will be a decreasing amount of work because of the shortterm impact of technology. The impact of this on women's employment is difficult to assess in New Zealand but certainly warrants further investigation. The repeal of pay equity legislation will certainly not help the cause of those women who are confined to these core "female" occupational groupings.

Unless sound equal employment opportunities structures and processes are introduced, and unless encouragement is given to women to enter non-traditional fields, the multi-production process is likely to continue to be dominated by men.

Women in the elite service class will have some advantages. They will have the skills and education necessary to compete and they will also, because of higher wages, be able minimize their care responsibilities. However, the repeal of the Employment Equity Act 1990 will not help the cause of equal employment opportunity implementation in the private sector. Additionally the skills identified in Tomorrow's Skills will not be acquired by women unless equal educational opportunities are vigorously endorsed in the education system.

Maddock (1982) commented about the New Right in Australia:

The basic message is that the poor should give up some of their incomes and living standards to provide an incentive to the rich and the powerful in order that the latter may cause the economy to grow whereupon we may all share the benefits. The economic case is certainly not proven. On the philosophical and moral views we have each to make our own choice (p.60).

Women in New Zealand society are solidly represented in this country's poor. They already make up the greater proportion of elderly people on Guaranteed Retirement Income, solo parents, the unemployed and those employed in the twilight economy. The Employment Contracts Act is unlikely to ensure that any "higher wages" coming from "higher productivity" will fall to those women who, for a significant proportion of their lifetimes, will likely be the primary household earner.

\section{References}

Armstrong, N. (1989) The hand that rocks the cradle can rock the boat. Feminism, the right and the role of the state. Paper presented at the Women's Studies Association Conference, Christchurch, 25-27 August.

Boyer, R. (1987) Labour flexibilities: many forms, uncertain effects. Labour and society 12(1):107-129.

Brocklesby, J. (1984) Technological change and the labour process in New Zealand. New Zealand journal of industrial relations 9(3):211-216.

Campbell, G. (1991). Building the poverty prison. Listener and TV Times, 25 March, p.14-18.

Cook, H. (1984) The Early Childhood Workers' Union: an analysis of consciousness and praxis. New Zealand journal of industrial relations 9(1):5-9. 
Couchman, P.K. (1984) Towards the automated office. Technological change and office work in the New Zealand Public Service. New Zealand journal of industrial relations 9(3):177-193.

Crocombe, G.T., Enright, M.J. and Porter, M.E. (1991) Upgrading New Zealand's competitive advantage. Auckland, Oxford University Press.

Deaux, K. (1988). Social psychology. California, Brooks/Cole Publishing Company.

Department of Statistics (1990). Women in New Zealand. Wellington, Ministry of Women's Affairs.

Endwick, P. (1989). Multinationals and labour: a review of contemporary issues and concerns. New Zealand journal of industrial relations 14(2):119-132.

Gray, A. (1987) Women in struggle: the Wool Testing Authority - PSA dispute. Race, gender, class 6:7-23.

Lewis, N. (1991) Prospects for equal employment opportunity: a woman's choice. Sites 22 (Autumn):123-141.

Maddock, R. (1982). Economic policy and the New Right. In M. Sawer (ed.) Australia and the New Right. Sydney, Allen and Unwin.

Maharey, S. and Cheyne, C. (1990). A new agenda. Sites 22 (Autumn):2-5.

Matlin, M.W. (1987). The psychology of women. New York, Holt, Rinehart and Winston.

McMorran, F. (1991) Out but not down. New Zealand nursing journal (May):11.

Mumford, K. (1989). Women working. Economics and reality. Sydney, Allen and Unwin.

Neilson, D. (1990). New Zealand trade unionism in the New Times. Sites 20 (Autumn):80-98.

New Zealand Planning Council (1990). Tomorrow's skills. Wellington, New Zealand Planning Council.

Pahl, R.E. (1989). From "informal economy" to "forms of work": cross national patterns and trends. In R. Scase (ed.) Industrial societies: crisis and division in western capitalism and state socialism. London, Unwin Hyman.

Power, M. (1988) Women, the state and the family in the US: Reaganomics and the experience of women. In J. Rubery (ed.) Women and recession. London,Routledge and Kegan Paul.

Shipley, S.M. (1982) Women's employment and unemployment. Palmerston North, Department of Sociology, Massey University.

Walsh, P. (1990). The privatisation of social aspiration: trade unions in the New Times. Sites 22(Autumn):80-98. 